\title{
Delineation of Late Onset Hypoventilation Associated with Hypothalamic Dysfunction Syndrome
}

\author{
LOIC DE PONTUAL, DELPHINE TROCHET, SOPHIE CAILLAT-ZUCMAN, OTHMAN A. ABOU SHENAB, PIERRE BOUGNERES, \\ YANICK CROW, STEVE CUNNINGHAM, BLANDINE ESTEVA, LADA CINDRO HEBERLE, JULIANE LEGER, \\ GRAZIELLA PINTO, MICHEL POLAK, MAGDY HELMY SHAFIK, CHRISTIAN STRAUS, HA TRANG, ARNOLD MUNNICH, \\ STANISLAS LYONNET, ISABELLE DESGUERRE, AND JEANNE AMIEL
}

INSERM U781 [L.P., D.T., A.M., S.L., J.A.], Laboratoire d'Immunologie [S.C.-Z.], Service d'Endocrinologie Pédiatrique [G.P., M.P.], Département de Génétique [A.M., S.L., J.A.], Service de Neurologie [I.D.], Hôpital Necker-Enfants Malades, Paris, 75015, France; Service de Pédiatrie [L.P.], Hôpital Jean Verdier, Bondy, 93143, France; Department of Paediatrics [O.A.A.S.], Farwaniya Hospital, Mubarak Al Kabeer, 427430, Kuwait; Service d'Endocrinologie Pédiatrique [P.B.], Hôpital Saint Vincent de Paul, Paris, 75014, France;

Department of Genetic [Y.C.], St James University Hospital, Leeds, LS97TF, England; Department of Respiratory and Sleep Medicine

[S.C.], Royal Hospital for Sick Children, Edinburgh, EH91LF, Scotland, UK; Service d'Explorations Fonctionnelles [B.E.], Hôpital

Armand Trousseau, Paris, 75012, France; Pediatric Neurology Unit [L.C.H.], Al Sabah Hospital, Safat, C.N.13041, Kuwait; Service

d'Endocrinologie Pédiatrique [J.L.], Service de Physiologie; INSERM E9935 [H.T.], Hôpital Robert Debré, Paris, 75020, France; Pediatric Department [M.H.S.], Farwania Hospital, Salmiya, 2208, Kuwait; Service Central d'Explorations Fonctionnelles Respiratories [C.S.], Groupe Hospitalier Pitié-Salpétrière, Université Pierre et Marie Curie, Paris 6, EA2397, Assistance Publique-Hôpitaux de Paris, Paris, 75013, France

\begin{abstract}
Late Onset Central Hypoventilation Syndrome associated with Hypothalamic Dysfunction (LO-CHS/HD) is a distinct entity among the clinical and genetic heterogeneous group of patients with late onset central hypoventilation. Here we report a series of 13 patients with LO-CHS/HD. Rapid onset obesity is the first symptom of HD followed by hypoventilation with a mean delay of 18 mos. The outcome remains poor for this group of patients and would benefit from early diagnosis to anticipate ventilation and possible metabolic disorders. Tumor predisposition is more frequent than initially suspected and as high as $40 \%$ in this series. These tumors of the sympathetic nervous system (TSNS) are usually differentiated and do not significantly worsen the prognosis. We report a familial case with recurrence in siblings. The cause underlying LO-CHS/HD remains poorly understood although recurrence in siblings argues for a monogenic disorder. We ruled out PHOX2B, ASCL1, and NECDIN as disease-causing genes by direct sequencing in our series of patients and discuss possible disease-causing mechanisms. (Pediatr Res 64: 689-694, 2008)
\end{abstract}

$\mathrm{C}$ entral Hypoventilation Syndrome (CHS) is persistent central alveolar hypoventilation with or without apnoea during sleep (1). The first cases defined as resulting from central hypoventilation were acquired and secondary to trauma, vascular events, infections, or tumors (2). In 1970, Mellins et al. (3) reported the first case of idiopathic congenital central hypoventilation syndrome (C-CHS, Ondine's curse, MIM209880). A genetic basis for C-CHS was postulated because of, i) concordant monozygotic twins; ii) rare cases of recurrence in siblings and vertical transmission; and iii) the association with genetically determined neurocristopa-

Received May 29, 2008; accepted July 19, 2008.

Correspondence: Loïc de Pontual, M.D., Département de Génétique, Hôpital NeckerEnfants Malades, 149, rue de Sèvres, 75743 Paris Cedex 15, France; e-mail: depontual@necker.fr

Supported by the Agence Nationale pour la Recherche (ANR) and the Fondation pour la Recherche Médicale (FRM) (D.T.). thies (i.e. Hirschsprung disease and tumors of the sympathetic nervous system). The screening of genes involved in the developmental cascade of the autonomic nervous system pointed to $P H O X 2 B$ as the gene underlying C-CHS with an autosomal dominant mode of inheritance and de novo mutations in the first generation (4). We and others subsequently showed that $P H O X 2 B$ mutations also account for a subset of CHS presenting later in life and named Late-Onset Central Hypoventilation Syndrome (LO-CHS) (5-7). LO-CHS is genetically and clinically heterogeneous and a subset of patients presenting hypothalamic dysfunction (HD) in association with LO-CHS is clearly recognized as a distinct entity (8).

Single-case reports of LO-CHS/HD patients, one series and review of the literature have been reported and, thus, far (9-22) for a total of 30 patients to date. Here we present a series of 13 additional patients with LO-CHS/HD, one being a familial case with recurrence in siblings. This observation strongly argues that LO-CHS/HD is a monogenic condition. In this series, PHOX2B, ASCL1, and NECDIN have been ruled out as disease-causing genes by direct sequencing.

\section{PATIENTS AND METHODS}

Thirteen patients with LO-CHS/HD were referred to us between 2000 and 2007 and medical records were reviewed. Inclusion criteria were i) central hypoventilation confirmed by polysomnographic recordings with normal brain MRI and no lung or neuromuscular diseases and ii) at least one other sign of hypothamic dysfunction among the following: rapid-onset obesity due to hyperphagia, hyperprolactinemia, central hypothyroidism, water balance disorder, nonresponse to growth hormone stimulation test, corticotrophin deficiency, or abnormal puberty (precocious or delayed). 
The clinical data were first analyzed individually (Table 1). The data were subsequently compared with the 15 cases reported in the literature since 1965 (Table 2) and the series of LO-CHS/HD published recently (Table 3) by the mean of simple statistical tests. The results are presented as median or mean $\pm \mathrm{SD}$ for quantitative variables and as percentages for nonquantitative variables.

Genetic studies. Blood samples were obtained with informed consent and DNA was extracted according to standard protocols. The ethics approval for this study was obtained from the ethics committee of the Medical Faculty of Necker Hospital (CCPRB No. 95-05-03). We screened the coding sequence of the PHOX2B, ASCL1 (previously named HASH-1), and NECDIN genes by direct DNA sequencing. The conditions for the analysis of ASCL1 and $P H O X 2 B$ were as previously described $(9,10)$. Primers used for PCR amplification of the NECDIN gene were as follows: exon 1 (F 5'-GCACTTCCTCTCCAGGAATC-3'; R 5'-CTGGTTAGCCTCAGGTGCAG-3'), exon 2 (F 5'-ATGTGGTACGTGCTGGTCAA-3'; R 5'AACCATTCATCTGCCTCCAG-3'). The PCR reaction mixture $(25 \mu \mathrm{L})$ contained $100 \mathrm{ng}$ of leukocyte DNA, 20 pmol of each primer, $0.1 \mu \mathrm{M}$ dNTP, and $1 \mathrm{U}$ TaqDNA polymerase (Invitrogen, Cergy Pontoise Cedex, France). DNA sequencing was performed by the fluorometric method on both strands (Applied Biosystems, Courtaboeuf Cedex, France). HLA genotyping was performed after amplification of the DRB1 locus by PCR with specific primers, and hybridization with allele-specific oligonucleotide probes immobilized on membrane-based strips (InnoLipa HLA-DRB1 typing kit, Innogenetics).

\section{RESULTS}

Clinical data from patients with LO-CHS/HD. Thirteen patients with LO-CHS/HD were included in this series. Median age at diagnosis was 5 y (from 1 mo to 9 y). Eleven cases were sporadic and two patients were brother and sister with healthy, unrelated parents. Although sibling two presented hypothalamic dysfunction and hypoventilation from birth, he was included considering the more typical presentation of his older sister. The main clinical findings are provided in Table 1. The first symptom was rapid-onset obesity in 10 of 13 $(77 \%)$ cases, behavioral abnormalities in two (15\%) cases and alveolar hypoventilation in two $(8 \%)$ cases. Rapid-onset obesity because of hyperphagia occurred in 12 of 13 patients and behavioral abnormalities are mentioned in 6 of $13(46 \%)$ patients over the course of the disease.

Ventilation. Alveolar hypoventilation is consistent in our series as it was a mandatory criterion for inclusion. This choice aimed at collecting a homogeneous cohort of patients. Six of $13(46 \%)$ patients required full-time artificial ventilation although the remaining patients needed ventilatory support during sleep only. Ventilatory support was provided by tracheotomy and mechanical ventilation in seven (54\%) cases and positive airway pressure masks in six cases. When tested (seven cases), response to $\mathrm{CO}_{2}$ was impaired or absent.

Hypothalamic disorders. Disorders of water balance were frequent. At least one episode of severe hypernatremia $(>150$ $\mathrm{mM})$ was noted in $10(77 \%)$ patients whereas seven $(54 \%)$ patients presented at least one episode of hyponatremia $(<130$ $\mathrm{mM}$ ). Six patients presented episodes of both hyper- and hyponatremia. Thirst was frequently impaired whether increased, reduced, or even absent. Indeed, adipsia was noted in seven $(54 \%)$ patients and polydipsia in six (46\%) patients. When tested, the capacity for urine concentration was retained with and no effect on desmopressin, ruling out both diabetes insipidus and inappropriate antidiuretic hormone secretion. Growth hormone deficiency was reported in seven patients among whom four had a clinical manifestation with deceleration of their growth rate. Other hypothalamic disorders were as follows: central hypothyroidism (6), poor thermoregulation (6), hyperprolactinemia (5), adrenal insufficiency (4), and abnormal puberty (no puberty in three cases at $14 \mathrm{y}$ of age and precocious puberty in one case).

Dysautonomia. Ophthalmologic examination showed abnormal pupillary function in six cases, strabismus in five cases, and one case of bilateral ptosis.

Tumors of the sympathetic nervous system. Tumors of neural crest origin were identified in 5 of $13(39 \%)$ cases. In two of them, thoracic and abdominal scan with thin slides was necessary to detect a tumor and (123) I-metaiodobenzylguanidine (MIBG) scintigraphy was not contributive. All tumors were differentiated and noninvasive with ganglioneuroma in three cases and neuroblastoma with no $M Y C N$ amplification in two other patients.

Neurodevelopment. Cognitive impairment during the course of the disease was assessed in six patients. None are following a typical school program for their age. Mood disorders and abnormal behavior are frequent, with lethargy and/or irritability and aggressivity mentioned in all six cases. Sleep disorders are also observed, but circadian cycle inversion is not mentioned. Of note, decreased pain sensitivity is mentioned in three cases.

Outcome. In this series, two patients died at 1 mo and at five and a half years after the onset of the disease. The cause of death was acute hypoventilation in the first case and severe hypernatremia in the second case.

Genetic study. We screened the coding sequence of $P H O X 2 B, A S C L 1$, and NECDIN genes by direct sequencing in the 10 patients for whom DNA was available. No nucleotidic variations could be identified. We genotyped the HLA-DQ complex in nine patients and found five autoimmunity predisposing alleles, such as DQB $1 * 0201$, DQB $1 * 0202$, or DQB1*0302.

\section{DISCUSSION}

Idiopathic hypothalamic dysfunction was first described in 1982 as a probable consequence of the destruction or the degeneration of the hypothalamic-neurohypophyseal system, arising from the supraoptic and paraventricular nuclei of the hypothalamus (11). Known causes of HD include hypothalamic tumors (germinoma, glioma, pinealoma, craniopharyngioma, and metastases), Langerhans cell histiocytosis; local inflammatory, autoimmune, or vascular diseases; sarcoidosis; midline cerebral and cranial malformations, and surgical or other traumas (12).

We reviewed symptoms at onset, follow-up, and outcome in a series of 13 patients with LO-CHS/HD. The first manifestation was rapid-onset obesity, alveolar hypoventilation being noted later in the course of the disease with a mean of $1.5 \mathrm{y}$. Behavioral changes are frequently reported as a burden, which motivated the use of neuroleptic drugs in two cases $(\mathrm{O} 28 \mathrm{e} 1$ and 0310). Of note, lethargy, irritability, or a confused state can be attributed to water balance disorders. In our experience, the prognosis of LO-CHS/HD remains poor with a fatal outcome in two of the 13 patients and socio-educative difficulties in survivors. 


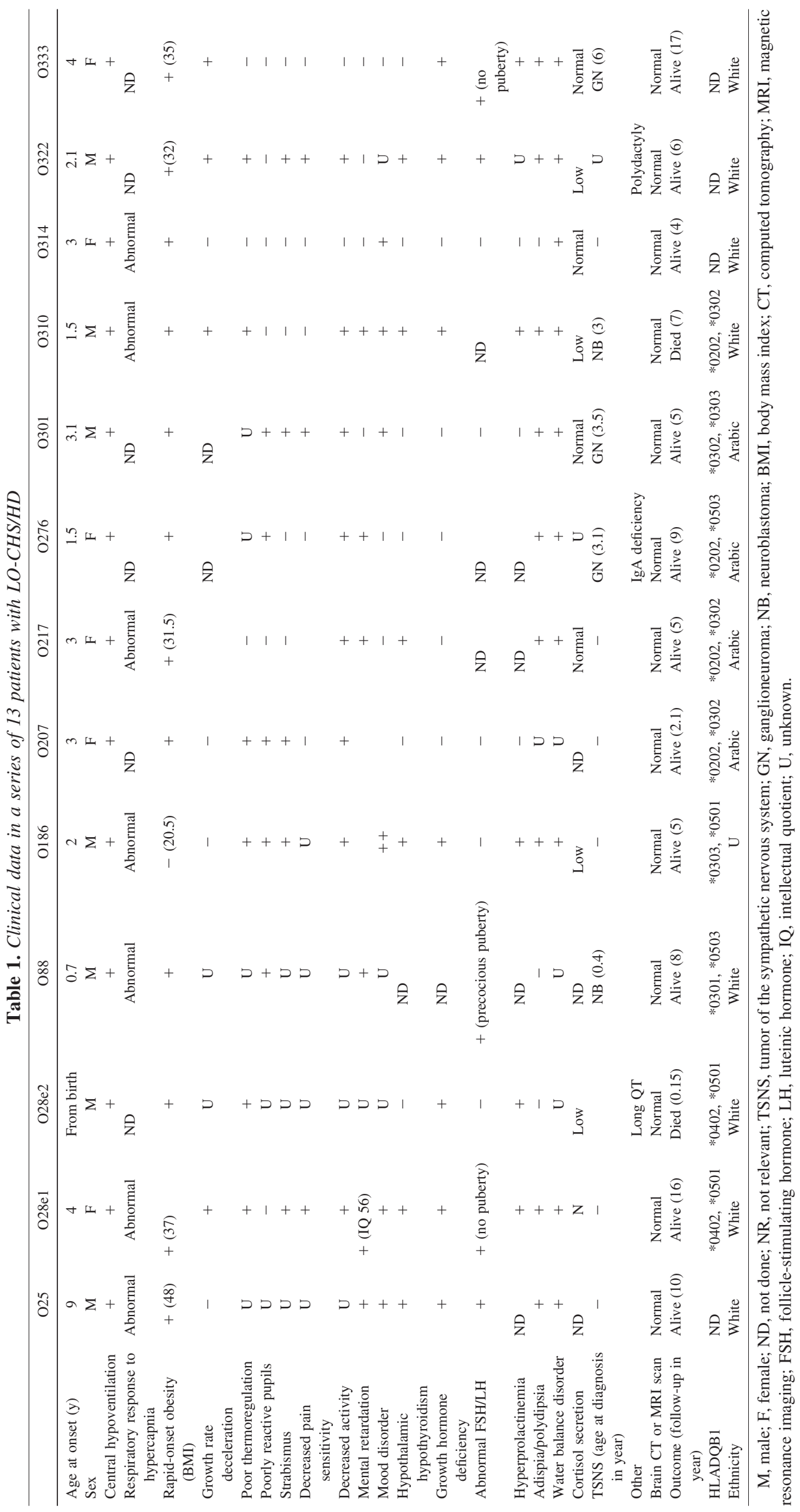




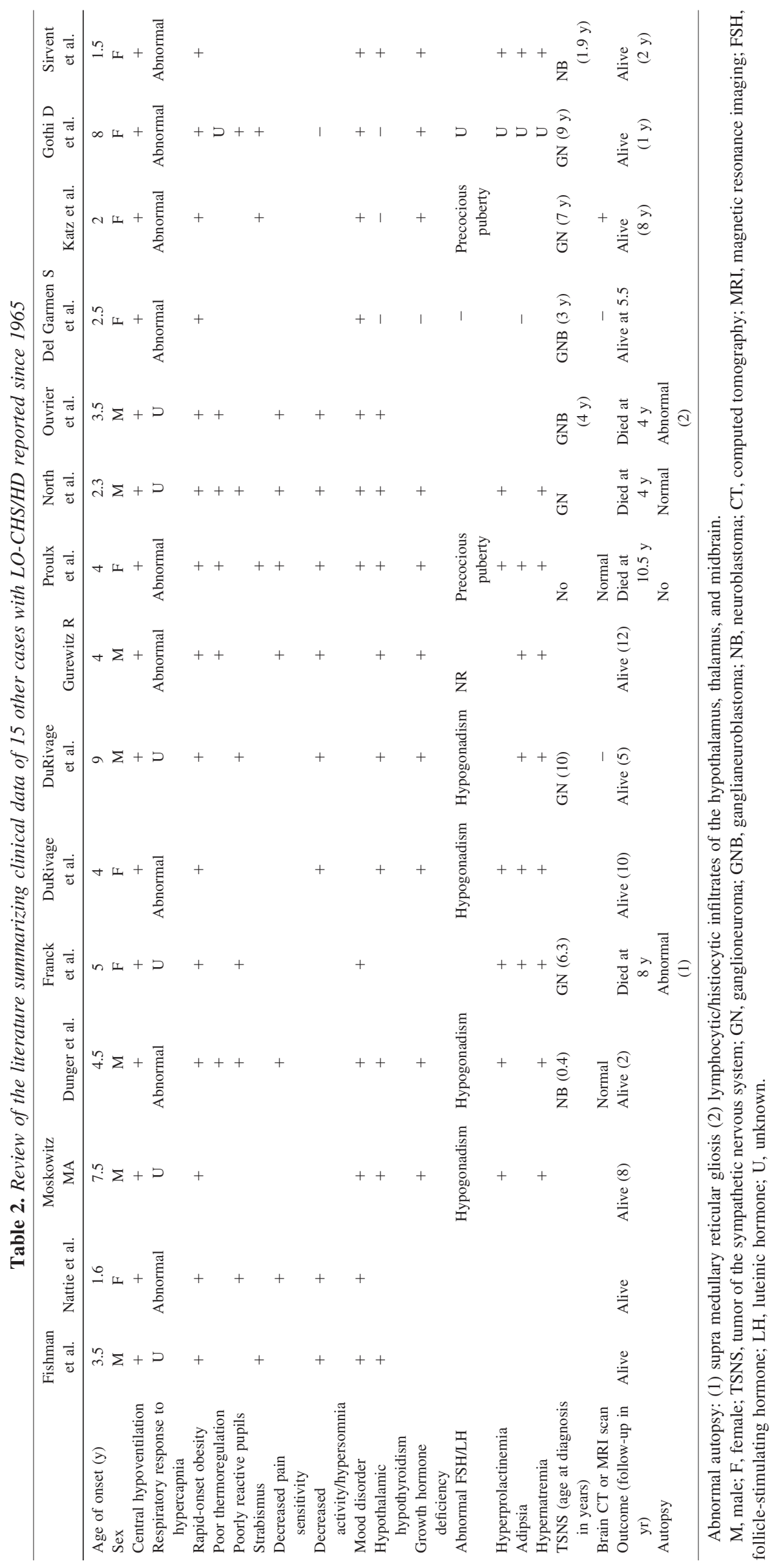


Table 3. Comparative study of all currently reported sporadic cases, the single reported series and this series

\begin{tabular}{|c|c|c|c|c|}
\hline & Series $(n=13)$ & Literature $(\mathrm{n}=15)$ & $\begin{array}{l}\text { Ize-Ludlow D et al. } \\
\qquad(\mathrm{n}=15)\end{array}$ & Total $(n=43)$ \\
\hline $\begin{array}{l}\text { Median age of } \\
\text { onset (y) }\end{array}$ & $5.3(0.4-7)$ & $4.5(1.5-10)$ & $3(2.17-4)$ & $3.9(0.4-10)$ \\
\hline Sex ratio $(M / F)$ & $0.54(7 / 6)$ & $0.47(7 / 8)$ & $0.4(6 / 9)$ & $0.46(20 / 23)$ \\
\hline $\begin{array}{l}\text { Rapid-onset } \\
\text { obesity }\end{array}$ & $11 / 13(84.6)$ & $15 / 15(100)$ & $15 / 15(100)$ & $43 / 43(100)$ \\
\hline $\begin{array}{l}\text { Central } \\
\quad \text { hypoventilation (\%) }\end{array}$ & 13/13 (100) & $15 / 15(100)$ & $15 / 15(100)$ & $43 / 43(100)$ \\
\hline $\begin{array}{l}\text { Behavioral } \\
\text { problems (\%) }\end{array}$ & $6 / 13(46.2)$ & $10 / 15(66)$ & $8 / 15(53)$ & $24 / 43(55)$ \\
\hline $\begin{array}{l}\text { Hypothalamic } \\
\text { hypothyroidism (\%) }\end{array}$ & $6 / 13(46.2)$ & $8 / 15(53.3)$ & $5 / 15(33)$ & $24 / 43(55)$ \\
\hline $\begin{array}{l}\text { Growth hormone } \\
\text { deficiency }(\%)\end{array}$ & $7 / 13(53.8)$ & $11 / 15(73.3)$ & 9/9 (100) & $27 / 43(62.7)$ \\
\hline $\begin{array}{l}\text { Abnormal } \\
\text { FSH/LH }(\%)\end{array}$ & $5 / 13(38.5)$ & $5 / 15(33.3)$ & $\mathrm{U}$ & $10 / 28(35.7)$ \\
\hline Hyperprolactinemia (\%) & $5 / 13(38.5)$ & $7 / 15(46.6)$ & $7 / 15(46.6)$ & $20 / 43(46.5)$ \\
\hline $\begin{array}{l}\text { Poorly reactive } \\
\text { pupils }(\%)\end{array}$ & $5 / 13(38.5)$ & $6 / 15(40)$ & $13 / 15(86.6)$ & $28 / 43(65.1)$ \\
\hline TSNS $(\%)$ & $5 / 13(38.5)$ & $8 / 15(53.1)$ & $5 / 15(33)$ & $18 / 43(41.9)$ \\
\hline $\begin{array}{l}\text { TSNS, median age } \\
\text { of diagnosis }(y)\end{array}$ & $6.6(0.4-8.5)$ & $7.5(0.4-10)$ & $4.2(2.8-6.8)$ & $6.1(0.4-10)$ \\
\hline $\begin{array}{l}\text { Median } \\
\quad \text { follow-up (y) }\end{array}$ & $5(0.4-16)$ & $4.3(0.5-10)$ & $\mathrm{U}$ & $4.8(0.4-16)$ \\
\hline Mortality & 2/13 (15.4) & $4 / 15(26.6)$ & $1 / 15$ (6.6) & $8 / 43$ (18.6) \\
\hline
\end{tabular}

Ranges are indicated into brackets.

M, male; F, female; TSNS, tumour of the sympathetic nervous system; FSH, follicle-stimulating hormone; LH, luteinic hormone; U, unknown.

Although rare in other LO-CHS entities, mental retardation is frequent in LO-CHS/HD patients in this series (six of 13; $34 \%$ ). Neurocognitive deceleration appears at the onset of the disease although neurologic development had been considered to be in the normal range before. It remains difficult to assess whether mental deterioration occurs per se over the course of the disease or whether it is only secondary to metabolic disorders and/or hypoventilation in LO-CHS/HD. Early diagnosis is needed to equilibrate electrolytes and hormones, and to sustain adequate ventilatory support from onset. In case O310, adequate ventilatory support had no positive effect on cognition; a frontal disorder was assessed by neuropsychological evaluation and slow frontal wakes on EEG. Of note, other known genetic defects of pituitary development are frequently associated with mental retardation (such as FOXE-1/FKHL15 and $N K X 2.1$ (13)).

Unlike LO-CHS, both LO-CHS/HD and C-CHS have been associated with tumors of neural crest origin (14) (8). Indeed, tumors of the sympathetic nervous system (TSNS) (i.e. ganglioneuroma and/or neuroblastoma) were diagnosed during the course of the disease in five of 13 patients from this series. Little is mentioned about such tumors in a series reported recently (15). Putting together the series we reported and case reports, a TSNS was identified in 13 of 28 cases classified as follows: ganglioneuroma (7), ganglioneuroblastoma (2), and neuroblastoma stage 1 (3). Age at onset of CHS is significantly younger in the group with no TSNS (3.6 versus $7.5 \mathrm{y}$ old age, $p<0.01$ ) and TSNS does not appear as a reliable prognostic factor. However, because these tumors are almost always differentiated and quiescent, their frequency may be underestimated.
LO-CHD/HD may be a paraneoplastic syndrome as proposed by North et al. (16). Interestingly, necropsy of two patients with LO-CHS/HD revealed a TSNS (ganglioneuroma in one case and ganglioneuroblastoma in the other case) associated with lymphocytic infiltrates of the hypothalamus and the thalamus $(16,17)$. Paraneoplastic manifestations in neuroblastoma have already been described with the opsoclonus-myoclonus syndrome being the most frequent (18). However, autoantibodies such as anti-Hu have never been identified in the CSF of LO-CHS/HD patients. Moreover, TSNS are frequently diagnosed 1 to $2 \mathrm{y}$ after the onset of the disease in LO-CHS/HD and surgery to remove the tumor does not seem to improve the outcome. Autoimmune LO-CHS/HD etiology is another hypothesis. Of note, one patient from this series (patient O276) has a complete IgG A deficiency, known to predispose to autoimmunity. In a recent familial case of narcolepsy where affected individuals did not carry the HLA DQB1*0602 autoimmunity-predisposing allele found in almost all other patients, a mutation in the hypocretin gene was found $(19,20)$. Hypocretin neurons are localized in the lateral hypothalamus and their destruction lead to narcoplepsy. Interestingly, no autoimmunity predisposing allele segregates in the familial case of LO-CHS/HD. However, a larger series of patients is needed to conclude whether these preliminary results are significant and, importantly, predisposition to TSNS could hardly find an explanation according to the hypothesis of LO-CHS/HD being an autoimmune disorder.

All LO-CHS/HD cases reported previously have been sporadic, with men and women being similarly affected. We report a familial case with a brother and a sister born to healthy, nonrelated parents, being affected. This evokes an 
autosomal recessive or an autosomal dominant mode of inheritance with de novo mutation in most cases and germline mosaicism in one of the parents in the case with sibling recurrence. Monogenic inheritance of LO-CHS/HD is also based on animal models presenting both hypothalamic dysfunction and abnormal control of ventilation. Among these models, Necdin mutant mice have shown an abnormal respiratory rhythmogenesis and hypothalamic insufficiency $(21,22)$. The NECDIN gene in human maps to $15 \mathrm{q} 11-\mathrm{q} 13$ at the Prader-Willi syndrome locus (PWS, MIM 176270). Patients with PWS can present endocrine abnormalities and respiratory manifestations but no tumor predisposition. However, no mutation in the coding sequence of the NECDIN gene could be identified in the nine LO-CHS/HD cases studied.

Among genes implicated in both peripheral and CNS development, we also tested $A S C L 1$ as a candidate gene for two reasons. First, Mash1, the murine homolog of ASCL1, is expressed throughout the basal retrochiasmatic neuroepithelium and is required for the generation of ventral neuroendocrine neurons (23). Second, ASCL1 is a potential modifier gene of $P H O X 2 B$ in C-CHS (9). We also studied the sequence of $P H O X 2 B$, as it is the disease-causing gene in both C-CHS and a subset of LO-CHS, in LO-CHS/HD. We identified no mutations in the ASCL- 1 or $P H O X 2 B$ coding sequence in this series. These negative results strongly argue for genetic heterogeneity within the group of patients with LO-CHS. Serotonin and $\beta$-endorphin pathways are two other interesting candidate cascades. Serotoninergic neurons are found in the anterior ventromedial hypothalamus, and the respiratory control centers and their impairment could result in both hypothalamic dysfunction and central hypoventilation. Increased endorphin production leads to increased prolactin production and inhibition of gonadotrophin-releasing hormone and thyroid-stimulating hormone release. Moreover, $\beta$-endorphin diminishes the central respiration drive. Altogether, identification of the genetic causes underlying LO-CHS/HD will shed light on links between hypothalamic function, ventilation, and tumor predisposition.

Acknowledgments. We thank the patients and their family for active participation in the study, the clinicians in charge of patients, and Dr. D. Sommelet and the Société Française d'Endocrinologie et Diabétologie Pédiatrique (SFEDP) for discussion.

\section{REFERENCES}

1. Gozal D 1998 Congenital central hypoventilation syndrome: an update. Pediatr Pulmonol 26:273-282

2. Berger AJ, Mitchell RA, Severinghaus JW 1977 Regulation of respiration (first of three parts). N Engl J Med 297:92-97
3. Mellins RB, Balfour HH Jr, Turino GM, Winters RW 1970 Failure of autonomic control of ventilation (Ondine's curse). Report of an infant born with this syndrome and review of the literature. Medicine (Baltimore) 49:487-504

4. Amiel J, Laudier B, Attie-Bitach T, Trang H, de Pontual L, Gener B, Trochet D, Etchevers H, Ray P, Simonneau M, Vekemans M, Munnich A, Gaultier C, Lyonnet S 2003 Polyalanine expansion and frameshift mutations of the paired-like homeobox gene PHOX2B in congenital central hypoventilation syndrome. Nat Genet 33:459461

5. Trochet D, Bourdeaut F, Janoueix-Lerosey I, Deville A, de Pontual L, Schleiermacher G, Coze C, Philip N, Frebourg T, Munnich A, Lyonnet S, Delattre O, Amiel J 2004 Germline mutations of the paired-like homeobox 2B (PHOX2B) gene in neuroblastoma. Am J Hum Genet 74:761-764

6. Trang H, Laudier B, Trochet D, Munnich A, Lyonnet S, Gaultier C, Amiel J 2004 PHOX2B gene mutation in a patient with late-onset central hypoventilation. Pediatr Pulmonol 38:349-351

7. Weese-Mayer DE, Berry-Kravis EM, Zhou L 2005 Adult identified with congenital central hypoventilation syndrome-mutation in PHOX2b gene and late-onset CHS. Am J Respir Crit Care Med 171:88

8. Katz ES, McGrath S, Marcus CL 2000 Late-onset central hypoventilation with hypothalamic dysfunction: a distinct clinical syndrome. Pediatr Pulmonol 29:62-68

9. de Pontual L, Nepote V, Attie-Bitach T, Al Halabiah H, Trang H, Elghouzzi V, Levacher B, Benihoud K, Auge J, Faure C, Laudier B, Vekemans M, Munnich A, Perricaudet M, Guillemot F, Gaultier C, Lyonnet S, Simonneau M, Amiel J 2003 Noradrenergic neuronal development is impaired by mutation of the proneural HASH-1 gene in congenital central hypoventilation syndrome (Ondine's curse). Hum Mol Genet 12:3173-3180

10. Trochet D, O'Brien LM, Gozal D, Trang H, Nordenskjold A, Laudier B, Svensson PJ, Uhrig S, Cole T, Munnich A, Gaultier C, Lyonnet S, Amiel J 2005 PHOX2B genotype allows for prediction of tumor risk in congenital central hypoventilation syndrome. Am J Hum Genet 76:421-426

11. Hayek A, Peake GT 1982 Hypothalamic adipsia without demonstrable structural lesion. Pediatrics 70:275-278

12. Traggiai C, Stanhope R 2004 Body mass index and hypothalamic morphology on MRI in children with congenital midline cerebral abnormalities. J Pediatr Endocrinol Metab 17:219-221

13. Gruters A, Krude H, Biebermann H 2004 Molecular genetic defects in congenital hypothyroidism. Eur J Endocrinol 151:U39-U44

14. O'Brien LM, Holbrook CR, Vanderlaan M, Amiel J, Gozal D 2005 Autonomic function in children with congenital central hypoventilation syndrome and their families. Chest 128:2478-2484

15. Ize-Ludlow D, Gray JA, Sperling MA, Berry-Kravis EM, Milunsky JM, Farooqi IS, Rand CM, Weese-Mayer DE 2007 Rapid-onset obesity with hypothalamic dysfunction, hypoventilation, and autonomic dysregulation presenting in childhood. Pediatrics 120:e179-e188

16. North KN, Ouvrier RA, McLean CA, Hopkins IJ 1994 Idiopathic hypothalamic dysfunction with dilated unresponsive pupils: report of two cases. J Child Neurol 9:320-325

17. Ouvrier R, Nunn K, Sprague T, McLean C, Arbuckle S, Hopkins I, North K 1995 Idiopathic hypothalamic dysfunction: a paraneoplastic syndrome? Lancet 346:1298

18. Matthay KK, Blaes F, Hero B, Plantaz D, De Alarcon P, Mitchell WG, Pike M, Pistoia V 2005 Opsoclonus myoclonus syndrome in neuroblastoma a report from a workshop on the dancing eyes syndrome at the advances in neuroblastoma meeting in Genoa, Italy, 2004. Cancer Lett 228:275-282

19. Peyron C, Faraco J, Rogers W, Ripley B, Overeem S, Charnay Y, Nevsimalova S, Aldrich M, Reynolds D, Albin R, Li R, Hungs M, Pedrazzoli M, Padigaru M, Kucherlapati M, Fan J, Maki R, Lammers GJ, Bouras C, Kucherlapati R, Nishino S, Mignot E 2000 A mutation in a case of early onset narcolepsy and a generalized absence of hypocretin peptides in human narcoleptic brains. Nat Med 6:991-997

20. Mignot E, Lin L, Rogers W, Honda Y, Qiu X, Lin X, Okun M, Hohjoh H, Miki T, Hsu S, Leffell M, Grumet F, Fernandez-Vina M, Honda M, Risch N 2001 Complex HLA-DR and -DQ interactions confer risk of narcolepsy-cataplexy in three ethnic groups. Am J Hum Genet 68:686-699

21. Pagliardini S, Ren J, Wevrick R, Greer JJ 2005 Developmental abnormalities of neuronal structure and function in prenatal mice lacking the prader-willi syndrome gene necdin. Am J Pathol 167:175-191

22. Muscatelli F, Abrous DN, Massacrier A, Boccaccio I, Le Moal M, Cau P, Cremer H 2000 Disruption of the mouse Necdin gene results in hypothalamic and behavioral alterations reminiscent of the human Prader-Willi syndrome. Hum Mol Genet 9:3101-3110

23. McNay DE, Pelling M, Claxton S, Guillemot F, Ang SL 2006 Mash1 is required for generic and subtype differentiation of hypothalamic neuroendocrine cells. Mol Endocrinol 20:1623-1632 